\title{
Muslim Women's Roles in Early Childhood Education
}

\author{
Munirah $^{1}$ \\ IAIN Sultan Amai Gorontalo, Indonesia
}

DOI: https://doi.org/10.21009/JPUD.132.05

Accepted: August $15^{\text {th } 2019}$. Approved: September $4^{\text {th }} 2019$. Published: $30^{\text {th }}$ November 2019

\begin{abstract}
The role of Muslim women in early childhood education is very urgent in education because women are the first source of knowledge for children. There are many supporting and inhibiting factors for the role of Muslim women executors. This study aims to find the role of female educators in Islam as a dual function that functions as a teacher, parent, and community member. The research method uses qualitative with a phenomenological approach. The findings show the role of Muslim women is not ideal, including the role of women as educators in schools, parents, and education experts. Women's awareness of early childhood education is still very low. Suggestions for future research to dig deeper into the causes of the role of women is still low, and influence government policy in increasing the role of Muslim women or non-Muslim women.
\end{abstract}

Keywords: Role of Muslim Women, Early Childhood Education

${ }^{1}$ Corresponding Author:

Email: munirah@iaingorontalo.ac.id 


\section{INTRODUCTION}

Women always play an important role in human development, but the roles are largely unmarked and not recognized. In very few cultures, until relatively recently, women were recognized to have the same role as men and had the same right to participate in all social fields. Muslim women have the same role in society but show that society depends on women as caregivers, child educators, academics for the development of children both at home and at work (Khan, 2003). Women make up half of the community and they are responsible for nurturing, guiding and reforming the next generation of men and women by educating and bringing early children to the appropriate ECE institutions. It is women who instill principles and faith into the souls of the nation and raise children of noble character.

New trends and family patterns have been paralleled by changes in gender roles, especially expanding the role of women into economic providers for families, this makes the focus of women on childcare and education divided. Developments related to the new role of women are seen as weakening the family (Frejka, Goldscheider, \& Lappegård, 2018). Women as mothers are the first madrasas for children to have been displaced because women's roles have shifted to being responsible for the family economy. To understand the everyday reality of modern society, it is necessary to recognize that the family is a dynamic entity, characterized by increasing complexity in relation to the decision-making process related to the transition in the course of family life and the organization of family life. Indeed, family can no longer be described only as a well-defined set of roles; it is negotiated every day, built by interactions between partners at the micro level. Work life and family are increasingly influencing each other because both women and men are involved in earning and caring.

Based on this phenomenon, women's critical awareness is needed, about their role in early childhood education. especially acting as an early childhood teacher both in the institution and in their homes when she was a mother. Kohli, Lin, Ha, Jose, \& Shini, (2019)'s research revealed critical awareness that was embedded in the position of women, in all domains of women's lives, not something that was processed only in education. Through family and community, critical education experiences and ongoing access to critical discourse, critical awareness is a way to understand and at the same time the existence of women in the world of education. A complex and sustainable workforce that develops into justice-oriented teachers, believes that teacher education programs and schools must recruit and support women who are already involved in developing their critical awareness.

The United Nations Sustainable Development Goals provide a historic opportunity to implement interventions, at scale, to promote early childhood development. Britto et al., (2017) review concludes that to make interventions successful, intelligent and sustainable, it needs to be implemented as a multi-sectoral intervention package that is tethered to care fostering. Various studies emphasize that interventions for early childhood should be applied at times that are suitable for development during the life span and are built on the feasibility of improvement platforms. Interventions will continue to increase with the development of developmental science, evidence now strongly suggests that parents, caregivers and families need to be supported in providing care and protection so that early childhood can reach their developmental potential. Women's awareness of their role to be a part of giving intervention to children. Based on the background of the problem and previous research, the following research aims to examine the role of Muslim women in early childhood education. 


\section{THEORITICAL STUDY}

\subsection{Theoretical Study}

Before elaborating further on early childhood education in the perspective of Islamic education, it is first described about children both in language and terminology. Etymologically (language) found six kinds of expressions in mentioning children, name-ly: al-awlãd, al-banûn, al-atfãl, alghilmãn, al-ghulãm, and al-wildãn. The first two terms have the connotation of the opposite meaning; al-awlãd connotes negative meanings and al-Banon has positive connotations; therefore, it has its own implications in children's education (Shihab, 2001; Tafsir, 2000; Jamhari, 2003; Jum'ah, 2006; Mansur, 2009; Sumantri \& Syaodih, 2006; Sujiono, 2012; Suyadi, 2011; Suryana, 2014; Fauzia, 2017; Siregar, 2018).

First: biological children, namely the position of children caused by birth factors; Natural children, namely children born from their own womb. In the perspective of biological child, fiqh has consequences in sharia rights and obligations, namely inheritance rights and filial obligations. Second: ideological children, namely the position of a child who is not caused by birth factors and there is no relationship between sharia rights and obligations, but those rights and obligations are built on humanitarian values, obedience, and inner ties such as students, foster children, subordinates, and so on. The term ideology in the Indonesian Language Dictionary means "a set of systemic concepts; the way someone thinks or a human group; understanding, theory, and sociopolitical goals that combine." Referring to the two terms above, we find several terms in the Qur'an which all-mean "children", namely: aulãd, banûn or banîn, dzurriyah, and tifl. The difference in terms used by the Qur' an does not change the basic concept of what is meant by children, both biologically and ideologically. It can be understood from various commentaries written by the mufassir (scholars who are experts in the field of interpretation of the Qur'an), including M. Quraish Shihab. In the interpretation of al-Mishbah and some of the books he wrote, interprets the semantic meanings of the terms of the Qur'an above which illustrate the concept of the child as follows (Shihab, 2001).

\subsection{The concept of Aulãd}

The word aulãd is the plural form of the word walad, which means child. The word aulãd in the interpretation of Shihab is not in the sense of a child within a certain age limit, but a child in a general sense, so the word aulãd here can be interpreted as a child in various age and sex constraints. This means that the word aulãd also includes early childhood between 0-6 years. As stated in the Surah al-Tawbah / 9: 55); aulãd as "slander" (Surah al-Anfãl / 8: 28); aulãd as one who can "neglect from remembering God" (QS al-Munãfiqûn 63: 9); aulãd as something "not the cause of getting closer to Allah" (Surah Saba / 34: 37).

\subsection{The concept of al-Banûn}

The word al-banûn is a plural form of ibn, which means a male child (gender: dzakar), and ibnah or bint the plural form of banãt means a daughter (gender: untsã). From the root of the word ibn, several words are found in the Qur'an such as the word (بَنَى) banî, which means derivative, class of followers, or folk, and the word (بُنََّ) bunayya, which means a child who is still in young age.

The word al-banûn is contextually the opposite (antonym) of the word aulãd, which tends to be pessimistic. The word al-banûn in the terminology of the Qurran has an optimistic connotation, as illustrated in several verses of the Qur'an that relate the word al-banûn to zinah, as found in 
verse 46 of the surah al-Kahf and al- banîn with (زُيَّ) zuyyina, as found in verse 14 of surah Ali Im-ran. Both words are interpreted as "decoration" or "made beautiful".

Therefore, the word (بنيّ) bunayya taken from the ibny word is a patron that describes delusion. The collection describes love, as Luqman calls upon his son in verse 13 of Surah Luqmn that

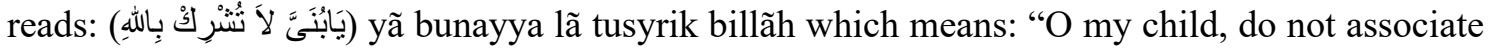
with Allah". Luqman called upon his sons by labeling them bunayya. According to Shihab, describing Luqman's affection for his small child is about loving. In terms of substance, the word al-banûn is the same as the meaning of aulād, which is a general understanding of "child", which includes children in all ages as children in the sense of the above. The difference between them lies in the context used; it is more on the things that are pessimistic while the allegiance is more on optic-mystical matters.

\subsection{The Concept of al-Zurriyyah}

The word zurriyyah, which means a child who is born of the womb of a mother (biological child) among them as mentioned in the Surah al-A'rãf / 7: 172: "(And when your Lord took the descendants of the children of Adam from their moth-er)". Also, in the QS al-Ra'd/13: 38: "And verily We have sent several Apostles be-fore you and we gave them wives and descendants".

\subsection{The Concept of Tifl}

One of the names in the Qur'an, which is closer to the understanding of early childhood in this discussion, is tifl. This term is referred to in the Qur'an four times, two of which are referred to in two verses in the same surah, namely QS al-Nûr / 24: 31 and 59. One of them takes the plural form atfãl, namely in verse 30. Another verse takes the singular form of tifl, namely Surah alHajj, 22: 5; QS Ghãfir/Mu'min, 40: 67; and QS al-Nûr/24: 59.

The word tifl (singular form) indicated by the verses above all points to the understanding of early childhood as found in QS al-Nûr, 24:31 (or children who do not understand the female genitals). The general theme of this verse is the boundary of adult female genitals that should not be seen in the presence of normal and adult men. If so, then what is meant by tifl in this verse is that children who are still early in age are declared Shihab as "immature" or "have not understood sex". As Shihab interprets the word tifl which is found in Surah Ghãfir and Mu'min / 40: 67 which sounds: "He who created you from the ground then from a drop of semen, after that from a lump of blood, then you are born as a child". According to him, the word tifl in the last verse is the deadline of the process of human development in the womb, which starts from the beginning of its creation to birth in the form of tifl (baby). The word tifl is used by the Qur'an to refer to children who have not grown up, or children who have just come to the age of knowing the au-rat. The ațfãl word which takes the plural, usually refers to children who already know a little about sex / genitalia. Therefore, in QS al-Nûr / 24: 59 use the plural.

While the limitation of the age of children and children according to the scholars stopped at the age of twelve, so-called children are people who have not experienced wet dreams. Early Childhood Education (PAUD) is a basic educational level which is a training effort aimed at children from birth to the age of six years which is carried out through the provision of educational stimuli to help growth and physical and spiritual development in order to have readiness to enter further education held on formal, non-formal and informal channels. In other words, the notion of early childhood education is education that serves to assist the growth and physical development and 
psychological development of students aged zero to six years, which are carried out inside and outside the family environment.

\section{METHODS}

This research uses qualitative research (Miles \& Huberman, 1984). To consider holistically the phenomena on what is experienced by the research subjects, for example, behavior, perception, motivation, action as a whole, by means of descriptions in the form of words and language, when discussing natural special contexts (Yusmawati \& Lubis, 2019). Researcher directly witnesses the facts on the ground. Therefore, the research was carried out by collecting data was in accordance with reality in the field. This study discusses the role of Muslim women in early childhood education in Gorontalo City, which is the object of research that is reviewed directly by researchers in accordance with topics related to the findings in this study.

This study focuses on the reality of early childhood education in the city of Gorontalo, the role of Muslim women in the implementation of early childhood education in Gorontalo City. In doing this study, the author analyses supporting factors and obstacles to the role of Muslim women in the implementation of early childhood education in Gorontalo City; supporting factors and hampering the role of Muslim women in the implementation of early childhood education in Gorontalo City. It also aims to provide solution to the role of women in the implementation of early childhood education in Gorontalo City. In this study, the author focused on the role of Muslim women in early childhood education in Gorontalo City. The author limits the focus of early childhood research in Gorontalo. The focus of the research is illustrated in the following matrix.

Table 1: Matrix of Focus Description

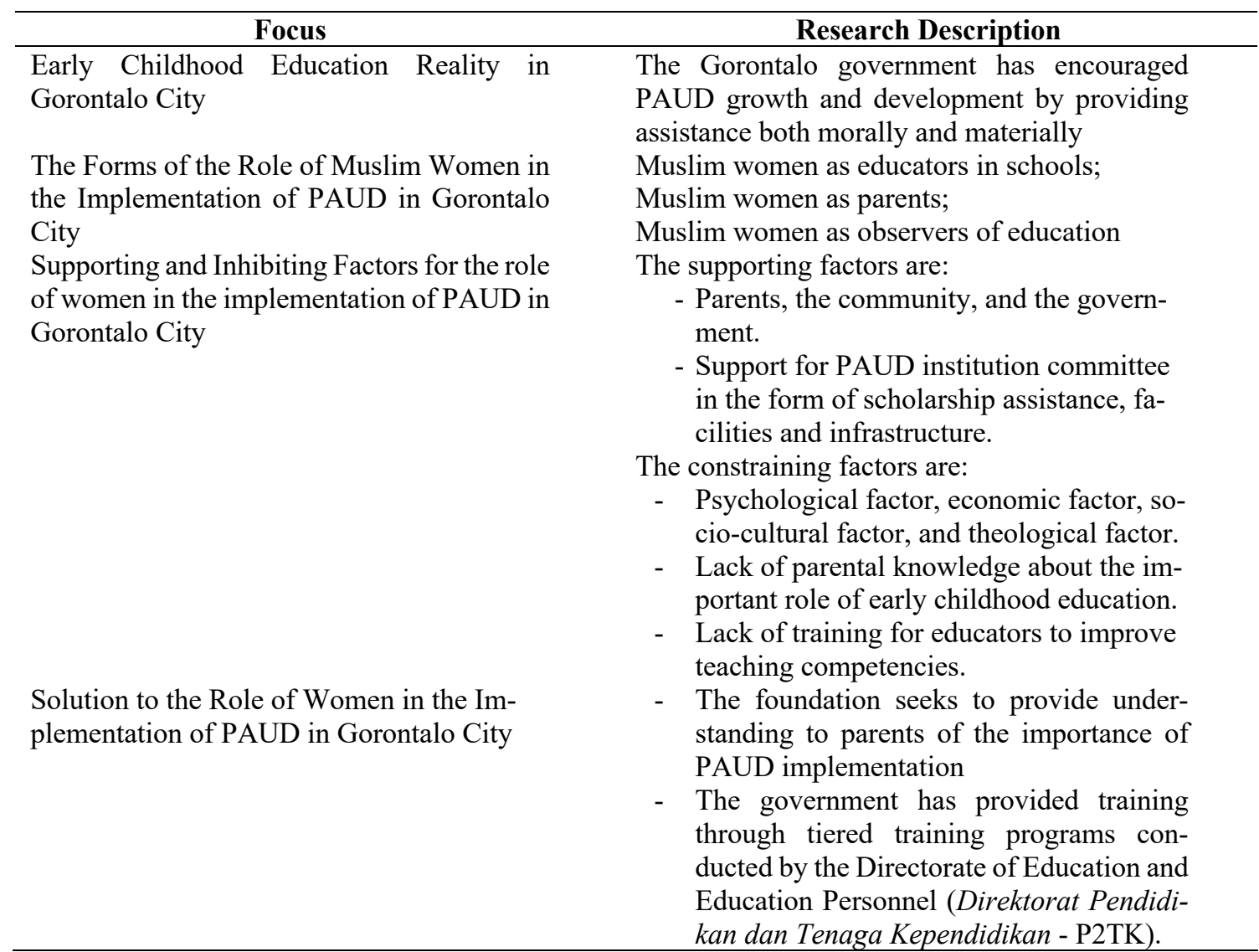

Source: The author, 2018. 


\section{RESULT AND DISCUSSION}

As a woman who plays a very important and valuable creature in carrying out her du-ties in nature, that is caring for and fostering children and the duties of the community (Edy, Ch, Sumantri, \& Yetti, 2018); (Islamiyati, 2018); (Megawangi, 1996); (Shihab, 2001); (Moeslichatoen, 2004); (Masnipal, 2013); (Kementrian Pendidikan dan Kebudayaan, 2013). Women are required to teach manners, moral principles, and human values to children. However, in modern times many women have been influenced by misleading views that ignore their duties and main roles as women. Many sexual deviations occur in the community that has never been witnessed in the life history of humanity.

Even though a woman works and slams, she will lose her temper and femininity, because women are created not as workers, but as wives, who are good for their hus-bands, educate, and nurture children in their homes. Although a house might be narrow and simple; for women, it is like a spacious and luxurious palace. Inside the house, women are better able to maintain and maintain their honor and glory than they have to be conductors, bus drivers and so on. If forced to help their husbands, let them carry out their duties or work that is in accordance with their mental and biological characteristics, such as nurses, caregivers and careers, educators, and participate in social activities justified by Is-lam, are far better for maintaining purity and his honor (Yamin \& Sanan, 2010). Therefore, as a form of women's role in the implementation of early childhood education, among others.

\subsection{Responsibility for Children}

\subsubsection{Caring for Children}

Muslim women must always remember that a mother's responsibility in educating children and forming her personality is greater than that of a father, because mothers are closer to them, more socialized and more aware of their circumstances, characteristics and behavior from growth to adulthood than the father. A true Muslim woman really knows her responsibilities in educating her children. He managed to instill noble values in their souls. There is no clear evidence of these values other than the main women task, that is, those are always aware of their roles to be succeeded in caring and educating their children. There children are expected to be the greatest impostors until there is hardly a figure from these devotees who have been slapped across various events in various times but he as a result of his great mother's prints.

\subsubsection{Educating Children Well}

The personality of a mother is usually close to children and is liked by them. They express their feelings and complain about problems, and the mother accepts the complaint and tries to overcome and influence their feelings by paying attention to their level of thinking and their time. Every now and then, he joked with them, stating pleasantly while giving advice and direction, guidance with gentle, loving words. Therefore, their love, attention and adherence to it increases to listen to advice and direction, and they obey it with full awareness that grows out of love and respect for the mother, not because of coercion or violence, where the two types of obedience are different. The first obedience arising from consciousness is true, strong and eternal obedience and will bring good results, while the second obedience that arises be-cause of violence and compulsion is false, temporary and obedience, which then dis-appears. This was revealed by Irmawati Utia Rahman, SP. who maintains: 
Educating children well must always show the personality of a mother, as a parent, show joy, so that children also feel close and can convey advice to children, direction, and guidance to children, with gentle words of affection, by getting used to - say kalimah tayyibah, like saying Subhanallah, Alhamdulillah, masya Allah, including getting used to greetings when meeting fellow Muslims. This can be done if parents take a role in this matter, starting with habituation (Irmawati Utia Rahman, a par-ent, interview, 26 May 2018).

\subsubsection{Giving Love and Kindness}

Muslim women whose hearts are illuminated by the sun will remember that their children need cool care, deep love, and pure tenderness, so that they grow with a healthy soul, far from various diseases and problems. His soul is full of optimism, his heart is full of confidence, and his brain is full of a myriad of hopes and ideals. For this rea-son, a mother must take her children with a cool water of love and tenderness that flows from the bottom of a big heart, to water their lives with excitement and pleasure, and fortify their souls with calm and confidence. Fonna B. Ino, expresses in this way:

As parents, and as Muslim women, they must educate children with love and tenderness. That way the child psychologically can feel closeness to the parents, so they can feel the love of their parents, someday he will pray for his parents, because he really gets love from his parents so surely he prayed for his parents as the recommended prayer means: that God forgive my parents as he loves me as a child. (Fonna B. Ino, a parent, interview, 29 May 2018)

Based on several of the interview above, it can be understood that when people educate their children with love and tenderness, one day children will also behave in a good and loving manner with their parents, as well as their children later.

\subsubsection{Be Fair to Children in Affection}

Wise Muslim women always do justice to their children by not prioritizing some of the others in each case because they know that unfairness is prohibited by Islamic law. Besides that attitude will have a negative impact on the soul of the child whose attention is reduced that is, that will grow in a state of inferiority, anxiety while saving envy and jealousy. While children who get fair attention by the mother, in order to make the children live healthy, clean heart from envy, resentment and inferiority. His soul is full of optimism, pleasure, love and grace. This is what Islam wants from parents, so he encourages them to do such attitudes.

\subsubsection{Do not bully children}

A Muslim woman who is aware is not permitted to curse her child in accordance with the Messenger of Allah's prohibition because it is feared that her oath coincides with the obligatory time. Sometimes it is found by parents who like to curse their children when they are angry, upset and so on; though it is prohibited in Islamic teachings. As a parent, he should not do such bullying. Muldiati Tone once rebuked one of the parents who became his neighbor in a polite manner he said:

"Whatever angry of a mother, as a parent, it should not be cursing her child with words like that (hopefully getting hurt if you don't want to hear Mother's words). The parental expressions are usually easy to accept. So that the Prophet forbade him to swear at children because he feared it would coincide with the time required". (Muldiati Tone, a local educational expert in Gorontalo, interview, 23 March 2018.) 
This opinion implies that the role of Muslim women in PAUD implementation in Gorontalo City, as the results of the interview above, is concerned about education of parents who educate their children who are deemed not in accordance with Islamic teachings, so that they take certain so that parents do not do so.

\subsection{Pay Attention to Things That Affect the Formation and Development of Children}

Muslim women who realize their religion without the knowledge of their children, they will monitor their activities, know their friends, their hobbies and wherever they go. When they found to be distorted, women's views, relationships, and hobbies must not be against Islamic teachings, such as, smoking and coming to a place of immoral. Furthermore, a Muslim mother who is cautious immediately negates her or warns her gently and wisely, because she is more able to do so from her husband because he is closer to them. Here, there is a great responsibility of a mother in directing her children and forming them into a pious generation whose personality is in accordance with Islamic values.

\subsubsection{Infusing Morals to Children}

Muslim women will earnestly instill good moral character in the souls of their children, in the form of love for others, love the weak, respect the great, love the smaller, establish friendship, love to do good, be honest, keep promises, and attitude other commendable attitudes which include noble character.

\subsubsection{Provide Advise and Pray for Children}

One of the tasks of educators is to advise their children so that children's behavior does not deviate. In addition, educator's advice can also build a healthy and clean child's personality. In terms of advice, the Prophet (peace and blessings of Allah be on him), always chose the right time and place to advise children, because thus, the burden of education will diminish, the results of education will be maximally achieved. In addition, the love of educators, especially parents, can be done by praying for children. Prayer is the main pillar that parents must practice for the good of children. Parents must beg sincerely and hopefully to God, because it is the traditions of the Prophets and messengers of Allah.

Just as the Prophet did in the history of Abu Musa's friend revealed by Ibn Hajar al-Asqalani and discussed specifically in a chapter on the importance of praying for the child for the blessing of the child, as the Prophet said to Abu Musa named Ibrahim. The Prophet. in praying for children, they always rub their heads and even rub the face of the child being prayed for. In addition, the role of Muslim women is quite a lot including the role of women as educators in schools, the role of women as parents, and the role of women as observers of education.

\subsubsection{Women as Educators in Schools}

As a person who is responsible for the development of students both in terms of affective, cognitive, and psychomotor, then an educator is required to understand their duties and responsibilities. In the implementation of the Al-Islah Islamic Integrated PAUD center in Gorontalo City, the educators have carried out their responsibilities as a manifestation of the holy intention in advancing the world of education. This was illustrated in an interview with PAUD teachers, for example Lian Muhungo who maintains:

"Since 2005, I graduated from college and immediately taught honorary teachers in PAUD. The main factor that drives me in-to the world of early childhood education is the field of sci-ence that 
I have obtained in college I want to immediately practice in direct learning activities and to see what results from the field of science that I have ever received. Besides that, I am also happy and like the world of children". (Lian Mo-hungo, a teacher of Raudhatul Athfal Sabilil Ilmi Kota Gorontalo, interview, 26 May 2018)

Therefore, educating is a call of heart and academic responsibility to apply the knowledge that is owned. Women are no exception. Lian added:

The role of women in early childhood education remains progressively visible. Wom-en play an important role in children's education, for example by the presence of playgroups and learning parks that help the community in developing education in Gorontalo Province. (Lian Mohungo, a teacher of Raudhatul Athfal Sabilil Ilmi Kota Gorontalo, interview, 27 May 2018.

A similar opinion expressed by Lely Sayedi who states:

"I taught at PAUD four years ago. The underlying motivation so that joining PAUD is to develop the knowledge I have. In addition, I want to help the government edu-cate children early. It is because early age kids liked to be a home foundation. If the foundation is strong and strong, then the house will last longer and not easily collapse" (a teacher of Raudhatul Athfal al-Ma'arif Kota Gorontalo, interview, 5 March 2018.)

Teachers' of PAUD concern above shows that they have a great soul, high sincerity, patience, and consistence (istiqamah). This evidently shows that educators have spiritual potential namely:

\subsection{Clean soul, body, and mature in thinking}

An educator must have a clean mind and body in carrying out his daily activities. Without a clean body and soul, a student will have difficulty in purifying his intentions and behavior in every professional action.

\subsubsection{Sincere}

In accordance with the intrinsic value of Islamic education, a teacher must be sincere in every academic dynamic. The value of sincerity will determine whether the learn-ing process can be successful or not. A teacher who is not sincere in every academic activity will be trapped by routine activities that are always based on material and personal satisfaction but will not achieve social satisfaction and spiritual satisfaction.

\subsubsection{Fair}

Educators must be fair, in every learning process; fair treatment to all students will arouse motivation for each student, because all the work and results of student achievement will be assessed fairly to give satisfaction to all students. There should be no teacher preference for students because this will lead to student discrepancies with the teacher. As an educator, to be being fair and not choosing the love of children are ones of the attitudes that must be possessed to make children obedient to educators. Thus, the injustice and favoritism of students towards their children as students creates jealousy and envy in the soul of the child because they feel they are set aside.

\subsubsection{Patience}

A teacher is required to be patient in devoting himself to students during school, which may be at this time the values have ranged or have been abandoned so that they cannot be blamed if a student sometimes does inappropriate or is against / insolent to the teacher. The sense of 'devoting oneself 
to children' is the teaching of the Father of Education, Ki Hajar Dewantara because each individual has his 'desire' by understanding children as different individuals who have different talents and interests so that in absorbing knowledge and practice it differently from one another. This is where a teacher is required to have extraordinary patience.

\subsubsection{Istiqamah (Consistence)}

Consistency of knowledge and consistency of attitude will determine whether the learning can be achieved or not. A student must be consistent in the knowledge, of what is taught, what is conveyed and what is done must have its istiqamah (consistency) value. The science taught must have a high scientific foundation and not just mere knowledge delivery. Consistency must underlie the knowledge we transfer because the values of truth are highly upheld by science. Besides that, the attitude of the attitude is also very necessary because it is very related to a good personality.

\subsection{5 'Alim (know well)}

A teacher must be pious, in the sense that because a teacher is an example for each student, then surely the teacher must have a pious character. Exemplary is something that is exemplary. Social education has a lot of influence on the behavior of others who are used as examples or examples that are imitated by children. The Gorontalo Provincial PAUD Mother, Idah Syahidah Rusli Habibi, said:

"Children are the owners of the present and future of the nation because in their hands the history of the lives of the next generation continues. So important they are in the chain of continuity of a nation's tradition. Age zero to six years is a golden period as well as a critical period in the stages of human life that will determine the development of children later. Ibu Idah also said that these times were the right time to lay the foundations of physical, language, social, emotional, selfconcept, art, morality, and religious values" (Idah Syahidah Rusli Habibi, a "mother" of PAUD in Gorontalo province, interview, 10 May 2018.)

Gorontalo Provincial PAUD Mother, Idah Syahidah Rusli Habibi, said that the Muslim women are the owners of the present and future of the nation because of their hands. So important they are in the chain of continuity of a nation's tradition. From zero age to six years is a period as well as a critical period in the stages of human life. It has been also held that these times were the right time to find the foundations of physical, language, social, emotional, self-concept, art, morality, and religious values. At this stage, Ibu Idah believes that:

Teacher's profession, especially PAUD teachers, as educators must be more dominant in cultivating students' mentality as early as possible. As a noble moral responsibility holder, women are important because childhood is an important time for sensitivity in cultivating mentality for education. Therefore, PAUD teachers need to explore history, the ins and outs of learning development of students who are at an early age. PAUD teachers are expected to develop new formulations, innovate and be compatible with the times. (Idah Syahidah Rusli Habibi, a "mother" of PAUD in Gorontalo province, interview, 10 May 2018)

As a result, it can be said that PAUD teachers are expected to be able to apply every effort to serve the intellectual life of the nation. Therefore, it is not about luxurious learning facilities, because luxurious facilities do not guarantee that children will have a high work ethic, and vice versa.

\subsection{Women as Parents}

The role of parents in this case is the mother and woman greatly determine the level of success of the education of their children. For this reason, children's education is not entirely left to teachers 
but also parents at home. The PAUD program needs to get support from all parties, including parents, the community and the government as observers of education. This is as illustrated in the results of interviews with parents of students which include:

\subsubsection{Parents as motivators for their children}

Children are the nation's assets that determine the future of the nation and the State so that they need to be nurtured and developed early. To realize optimal development children, need support from all parties. Fitrawati A. Husain, parents of Rifa J. Putri Husain stated:

Parents provide motivation and encouragement in the learn-ing process, interact with teachers in schools in terms of developing children's learning in school, and fulfill their basic needs. In addition, parents must pay attention to their procedures in providing education to their children, not eliminating children's enthusiasm in learning, giving support and attention so that children's confidence is not lost. (Fitrawati A. Husain, a parent, interview, 6 March 2018)

Saskia Novelia further adds:

To be a motivator for children, parents must give love and love unfortunately sincerely and always communicate and exchange ideas with children about every problem they face. (Saskia Novelia Biki, a parent, interview, 8 March 2018)

Based on the interview above, it can be understood that the importance of parents' care for children, especially in early childhood, as a form of responsibility in children's development. Because it is the role of parents that greatly influences their growth, because the amount of time for children and their parents is greater than the amount of time with the teacher.

\subsubsection{Parents as a model or role model for their children.}

For example, M. Sya'ban Karim states:

Parents are very important for children's education. Parents are the closest model and example for their children to imitate. For this reason, parents must teach their children how to behave politely, not say rude, and teach them how to respect older people (Sya'ban Karim, a parent, interview, 8 March 2018.).

\subsubsection{Parents as teachers at home. For example}

Irmawati Utiarahman, a parent state:

The role of parents at home is to guide the child and repeat what the child has gotten at school. For children, it is easy to learn but it is also easy to forget the lessons they have received if they are not repeated. For this reason, the role of parents as teachers at home is very important in maintaining the lessons that children have received at school. ( Irmawati Utiarahman, a parent, interview, 8 March 2018)

Muslim women must always remember that a mother's responsibility in educating children and forming her personality is greater than that of a father, because mothers are closer to them, more socialized and more aware of their circumstances, characteristics and behavior from growth to adulthood than the father.

\subsubsection{Parents as a determinant of improving the quality of children's education}

To improve the quality of children's education, teachers and parents must work to-gether to guarantee and improve the quality of children's education. This is illustrated in the interview with students' parents. For example, Saskia Novelia Biki maintains: 
Parents must teach their children to be diligent and active in learning both at school and at home. Always communicate to children by asking what lessons the teacher gives at school so that children can repeat them at home. Children must be trained independently both at school and at home. Providing writing stationery at home so that children can learn to write, draw, and color (Saskia Novelia Biki, a parent, interview, 9 March 2018).

Similarly, Saskia Novelia Biki, a parent argues in this way:

The important thing taught by a mother at home is: polite; where good things and bad things; how to write, draw and color; memorize short prayers and short verses; independent way of life (Saskia Novelia Biki, a parent, interview, 10 March 2018).

The parents realize that the environment has a great influence on the development of children's education. For this reason, it is necessary to oversee and supervise the social environment of children so that they are not trapped in negative things from their environmental influences. For example, A. Husain believes:

The child's family and social environment must be maintained from negative examples. For this it is necessary to improve a safe, orderly and peaceful household atmosphere so that children can concentrate fully on learning (Fitrawati A. Husain, a parent, interview, 10 March 2018.)

Similarly, M. Sya'ban Karim, a parent in Gorontalo expresses his opinion as:

The family environment has a big influence on the formation of children's character. By teaching children to speak politely and politely can form the character early on. In the community, with the variety of characteristics and characteristics of people met by children, parents must be selective and guide their children. This can be done by telling the child which example can be copied and which example should not be imitated Sya'ban Karim, a parent, interview, 10 March 2018.

In addition, as busy parents with various kinds of professions, they need awareness for every parent to be able to manage his time to be able to give special time to the education of their children. As for the method of education at home, between one parent and another has its own method. As Meilan Soleman, a parent says that:

"How to set the learning time of children at home is adjusted to the right time, if you are playing then do not force them to learn." Meilan Soleman, a parent, interview, 9 March 2018.

In a different view, M. Sya'ban Karim states in this way:

Education at home can be done at any time by utilizing objects that are around the house, it can even be done while playing so that the child does not get bored and does not seem impressed. For example, a child is playing cars, parents ask the child "what color is the car?", "How many wheels?", "What is this car?" M. Sya’ban Karim, a parent, interview, 10 April 2018.

Another opinion coined by Fitrawati A. Husain who sees that:

Children's education must be carried out at night after din-ner, at least repeating the material received at school in the afternoon. Fitrawati A. Husain, a parent, interview, 9 March 2018.

Similar to Fitrawati, the same thing was expressed by Irmawati Utiarahman:

Children's educational arrangements at home ie at night before bed the child must be accustomed to memorizing, learning to count, and reading. In addition, chil-dren are not allowed to play before learning. Irmawati Utiarahman, a parent, interview, 12 March 2018.

A more detailed division of time was carried out by Saskia Novelia Biki. He stated that: 
How to manage children's education at home is by dividing time. There is time to study, play and rest. Consistency with a predetermined time will teach children to understand the importance of living a disciplined life Saskia Novelia Biki, a parent, interview, 14 March 2018.

The benefits felt by parents after entering their children in PAUD al-Islah as revealed by Saskia Novelia Biki:

Knowledge of children increases is able to socialize so that they have many friends, so they can adapt to the social environment, and can understand which are good and which are bad.

The benefits of PAUD education are also felt by Sri Endang Pakaya, stating that:

Before my child entered PAUD, he had not been able to distinguish colors and was unable to count. Alhamdulillah, after entering PAUD he can now distinguish colors and be able to count. Saskia Novelia Biki, a parent, interview, 15 March 2018

The same thing was expressed by Meilan Soleman, mother of Fahrul Rauf who stated that:

Before entering PAUD, my child was a spoiled and not in-dependent child, but after participating in PAUD the spoiled behavior decreased and even his independence began to appear. Meilan Soleman, a parent, interview, 16 March 2018.

According to Irmawati Utiarahman:

The difference between children before and after PAUD is quite significant, including: children have the courage to ap-pear before many people, their knowledge is broader, more creative, and can get along with many friends Irmawati Uti-arahman, a parent, interview, 16 March 2018.

From the entire interviews above, it can be understood that early childhood education is very basic education and very decisive for future child development. This is supported by the statement of Idah Syahidah Rusli Habibi that: instinctively, the family, especially parents, is the first and foremost educators when children are born. Therefore, in fact we cannot forbid parents to send their young children to early childhood education institutions as desired.

\subsection{Women as Educational Observer}

Muslim women who understand their religion will know that man was not created in the world to be unemployed, but to fulfill a duty to carry the message and bear the task of carrying the message and carrying out the mandate, carrying out obligations in the form of worship to Allah Almighty. Worship to God is reflected in every positive and constructive movement and gait to advance the world, elevate the sentences on the earth, and apply His thought and system in life. All of this is a right that every Muslim must call to all humanity. So, the true Muslim woman feels obliged to pay attention especially in the world of education.

The real work of Gorontalo Muslim women as the Mother of Gorontalo Province PAUD, BUDA PAUD program One PAUD Hamlet, by holding a Training of District and City PAUD Management in Gorontalo Province which took place in the BPKB Hall of Gorontalo Province, Wednesday 12 March 2014. In her speech Idah Syahidah Rusli Habibi (Mother of PAUD Gorontalo Province) said that Early Child-hood Education is one form of education that focuses on laying the foundation to-wards physical growth and development, intelligence, socio emotional, language and communication, in accordance with the uniqueness and stages growth and development traversed by early childhood. As PAUD management has a very important role, of course, in managing PAUD institutions, managers are more focused on how to manage these PAUD institutions properly. Because community needs for PAUD institutions are very large. Ida Syahidah Rusli Habibi, a "mother" of PAUD of Gorontalo province, interview, 14 March 2018 
Furthermore, Gorontalo strived for one PAUD hamlet considering the vastness of the Regency and City area, Obviously Idah Syahidah said PAUD managers must have knowledge in planning, organizing, implementing and controlling the implementation of PAUD programs. In a sense, both in terms of institutional management and in the administration of program activities up to $5 \mathrm{~T}$ will be achieved that is appropriate, right on target, right on time, right on budget utilization, and right on funds, accountability. PAUD managers must be active in reading opportunities and opportunities, establish partnerships with SUBDIN PNFI and BPKB in Provinces with SKB and PKBM in Regencies and Cities. Ida Syahidah Rusli Habibi, a "mother" of PAUD of Gorontalo province, interview, 14 March 2018.

In addition, it is the Real Work of Muslim Women (Idah Syahidah Rusli Habibi, Gorontalo PAUD Hospital), maintaining health, and adopting a healthy lifestyle for early childhood. Idah Syahidah explained that maintaining health is very important in life because it is a good step to go through all activities in achieving life goals, if health is disturbed it will affect all the results that will be obtained also in achieving life goals later. It is said that healthy living is very difficult now, most of it is not due to genetic factors, but many are already affected by lifestyle. Deceases certainly can come to attack anyone indiscriminately; the disease will be very detrimental to our health because it can damage the body and of course cost a lot. Ida Syahidah Rusli Habibi, a "mother" of PAUD of Gorontalo province, interview, 16 July 2018 Although there is a free health program from the government; yet, some medical needs that must be bought by patients.

Based on the description above, it can be said that the form of the real work of Gorontalo Muslim women as the mother especially in taking care of health and education activities especially early childhood in Gorontalo City. Besides health and education, there is no neglect of children's song festivals in Gorontalo Province. Idah Syahidah (the mother of PAUD in Gorontalo) said that: in the current era of globalization the existence of children's songs has begun to become extinct which is gradually replaced by adult songs that cause early maturity or adulthood not yet in time to impinge on children because of influence because they often sing or listen to these adult songs Ida Syahidah Rusli Habibi, a "mother" of PAUD of Gorontalo province, interview, 14 March 2018.

With the participation and attention of the entire community, Gorontalo children can sing children's songs well so that singers or authors and songwriters will emerge, not just a victory that must be won, but the most important thing is the writing. That experience of children will encourage them to singing and to listen to by the whole community.

Thus, the mother of PAUD in Gorontalo, Idah Syahidah Rusli Habibi expressed her gratitude and gave a high appreciation to the parents. The parents mainly participated by inviting their children to the event and advised that parents always provide good character education to their children from the age early so that it will produce children of good quality, good morals, noble character, good manners that can be useful for the nation and country in the days to come Ida Syahidah Rusli Habibi, a "mother" of PAUD of Gorontalo province, interview, 25 June 2018.

Therefore, it can be said that a Muslim woman must behave like that to her children; she will monitor their activities because the child is born in a state of holiness in accordance with nature.

As a form of the real role and work of Muslim women in Gorontalo in the commemoration of National Children's Day and the PAUD Gebyar with the theme "Create Smart, Honest, and Noble Character". The activity was held at the Mess Haji Gorontalo City, Tuesday, June 17, 2014. No 
less than 1000 children of the district / city delegates participated in the celebration. In the commemoration, the mother of PAUD in Gorontalo further stated that:

With the commemoration of National Children's Day and PAUD Gebyar, children can be more diligent in worship, study hard and be devoted to parents. The big theme of the 2014 National Children's Day is "Indonesia One Stop Action on Violence against Children" is appropriate and relevant to the current situation often seen around and through print and electronic media the amount of violence against children both perpetrated by parents, families and by other people. Parents as the closest people to children must always speak soft words, give good teachings and monitor the relationships of children in the surrounding environment. Idah Syahidah Rusli Habibi, a "mother" of PAUD of Gorontalo province, interview, 17 June 2018.

Based on the above quote, it can be understood that in this way children will not feel afraid and threatened so that they can grow and develop properly and meet a bright future.

Furthermore, the mother of PAUD sometimes plays with PAUD children how it says that: I invite children to play by using educational games as a form of learning. Because the importance of the learning equation between school and at home. Excessive affection is poison to the child itself. Mother of PAUD and parents have the same responsibility to maintain and educate early childhood. He further said that: children always imitate what their parents do, so that it is important for parents to do good things in order to provide the maximum possible education for their children. On the other hand, Mother of PAUD said that this year parenting activities will be held and played together with the Mother of PAUD three times. As a result, we can obtain more even and maximum. Idah Syahidah Rusli Habibi, a "mother" of PAUD of Gorontalo province, interview, 17 June 2018.

Based on the above arguments, the pattern of child development in PAUD al-Islah was developed with several patterns. This was revealed by one of the Gorontalo PAUD al-Islah teachers that:

Guidance for children in PAUD al-Islah is carried out with several approaches in-volving various components, organizers, educators, students, and considering the available facilities and infrastructure. Kiki Rizki Rauf, a teacher at PAUD al-Islah Kota Gorontalo, interview, 25 May 2018.

In short, from the results of the fieldwork research, the pattern of PAUD al-Islah development shows that the guidance involved several components in PAUD, such as the foundation as education providers, educators or teachers, students and other existing elements.

\section{CONCLUSION}

Community understanding of PAUD is still low and regards PAUD or preschool as only complementary, is underestimated, and may not be so necessary. Even though the failure of education is often because of problems that are considered trivial and easy. The fact is that there are still many young children who have not received educational ser-vices, especially for the lower-class community that is the majority of the population who are in rural areas. This is due, among other things; women's awareness of the importance of education to early childhood is still very low. Awareness of the importance of PAUD is still low. This low awareness, directly or indirectly, shows the opportunity for children to grow and develop optimally because of the lack of opportunities to participate in PAUD. It is conceivable that children who do not have the opportunity to at-tend coaching through PAUD will color the life of the nation and state in the future. 
The level of awareness of women towards the provision of educational services for early childhood is still low. Although so far, the government and the community have conducted various PAUD service programs. However, the reality is that until now there are still many early childhoods who have not received education services.

PAUD and various perspectives can be concluded that early childhood is the golden age of the "golden age" period of cognitive, language and social emotional development experiencing its peak point. Late stimulation at this age has a long-term effect on a human's life. In other words, the limitations of cognitive, language, social and emotional development are the implications and detrimental decisions of the State. Then, PAUD becomes a basic and based education choice to create better educational inputs for further education. Moreover, elementary school admission requires the ability to read, write and count has become a major requirement for famous schools.

Expensive costs have become one of the factors of the low level of participation in PAUD; amount of funds that need to be spent by parents who send their children to kindergarten or playgroups are not significant. In addition to the amount of money, that is quite large, plus monthly money. Not to mention there is additional expenditure on additional activities at school. Under these conditions, parents will prioritize spending on funds only for the most important and urgent needs. Therefore, if they do not fully understand the importance of PAUD, the funds for this will not be a priority. To over-come this problem, the foundation as an organizer strives to provide understanding to parents of the importance of costs in the implementation and quality of PAUD services. The lack of students who register every year is due to the large number of similar educational institutions that are opened. To increase the number of students entering each year, the school makes it wise to require every teacher to look for children who have not yet entered PAUD to be invited to PAUD.

\section{REFERENCES}

Britto, P. R., Lye, S. J., Proulx, K., Yousafzai, A. K., Matthews, S. G., Vaivada, T., ... Bhutta, Z. A. (2017). Nurturing care: promoting early childhood development. The Lancet, 389(10064), 91-102. https://doi.org/10.1016/S0140-6736(16)31390-3

Edy, E., Ch, M., Sumantri, M. S., \& Yetti, E. (2018). Pengaruh keterlibatan orang-tua dan pola asuh terhadap disiplin anak. Jurnal Pendidikan Usia Dini, 12(1). https://doi.org///doi.org/10.21009/jpud.122.03

Fauzia, S. N. (2017). Perilaku keagamaan Islam pada anak usia dini. Jurnal Pendidikan Usia Dini, 11(2). https://doi.org/://doi.org/10.21009/jpud.092.07

Frejka, T., Goldscheider, F., \& Lappegård, T. (2018). The two-part gender revolution, women's second shift and changing cohort fertility. Comparative Population Studies, 43, 99-130. https://doi.org/10.12765/CPoS-2018-09en

Islamiyati, I. (2018). Hubungan kerjasama orang tua dengan perkembangan anak usia dini di kelompok bermain. Jurnal Pendidikan Usia Dini, 12(1). https://doi.org/://doi.org/10.21009//jpud.121.06

Jamhari, I. R. (2003). Citra Perempuan dalam Islam. Jakarta: Gramedia Pustaka Utama.

Jum'ah, A. (2006). ). Sayyidinā Muhammad Rasulillah ila al- 'Alamin. Cairo: Dār al-Farouk.

Kementrian Pendidikan dan Kebudayaan. (2013). Petunjuk Teknis Penyelenggaraan Pendidikan Anak Usia Dini. Jakarta: Direktorat Pembinaan Pendidikan Anak Usia Dini.

Khan, M. Z. (2003). Woman in Islam and Her Role in Human Development. In The Muslim World. Retrieved from http://onlinelibrary.wiley.com/doi/10.1111/j.1478- 
1913.1914.tb01384.x/abstract

Kohli, R., Lin, Y. C., Ha, N., Jose, A., \& Shini, C. (2019). A way of being: Women of color educators and their ongoing commitments to critical consciousness. Teaching and Teacher Education, 82, 24-32. https://doi.org/10.1016/j.tate.2019.03.005

Mansur. (2009). Pendidikan Anak Usia Dini dalam Islam. Jakarta: Pustaka Pelajar.

Masnipal. (2013). Siap Menjadi Guru dan Pengelola PAUD Professional. Jakarta: PT Elex Media Komputindo.

Megawangi, R. (1996). Perkembangan Teori Feminisme Masa Kini dan Mendatang serta Kaitannya dengan Pemikiran Keislaman, dalam Man-sur Fakih, et. al. Membincang Feminisme: Diskur-sus Gender Persfektif Islam. Jakarta: Risalah Gusti.

Miles, M. B., \& Huberman, A. M. (1984). Qualitative Data Analysis. London: Sage Publication. Moeslichatoen. (2004). Metode Pengajaran di Taman Kanak-kanak. Jakarta: PT Rineka Cipta.

Shihab, M. Q. (2001). Tafsîr al-Mishbâh. Jakarta: Lentera Hati.

Siregar, N. M. (2018). Peningkatan kecerdasan interpersonal melalui aktivitas fisik anak usia 4-5 tahun. Jurnal Pendidikan Usia Dini, 12(2). https://doi.org/://doi.org/10.21009/jpud.122.10

Sujiono, Y. N. (2012). Konsep Dasar Pendidikan Anak Usia Dini. Jakarta: PT Indeks.

Sumantri, M., \& Syaodih, N. (2006). Perkembangan Peserta Didik. Jakarta: Universitas Terbuka.

Suryana, D. (2014). Dasar-dasar Pendidikan TK. Jakarta: Universitas Terbuka.

Suyadi. (2011). Pegangan Bimbingan Konseling untuk PAUD. Yogyakarta: Diva Press.

Tafsir, A. (n.d.). Pendidikan Agama dalam Keluarga. Bandung: PT Remaja Rosdakarya.

Yamin, M., \& Sanan, J. S. (2010). Panduan Pendidikan Anak Usia Dini (PAUD). Jakarta: Gaung Persada (GP) Press.

Yusmawati, \& Lubis, J. (2019). The Implementation of Curriculum by Using Motion Pattern. Jurnal Pendidikan Usia Dini. https://doi.org/DOI:https://doi.org/10.21009/10.21009/JPUD.131.14 